\title{
Types, Signs and Peculiarities of Transition Interval in the Conditions of the Society Industrial Development
}

\author{
Anna Leonidovna Spesivtseva \\ Assistant, Department of Economics of Institute of Social and Humanitarian Technologies, \\ Tomsk Polytechnic University, Tomsk, Russia \\ Elena Vladimirovna Aristova
}

Senior lecturer, Department of Economics of Institute of Social and Humanitarian Technologies,

Tomsk Polytechnic University, Tomsk, Russia

Marina Vladimirovna Pluzhnik

Senior lecturer, Department of Economics of Institute of Social and Humanitarian Technologies, Tomsk Polytechnic University, Tomsk, Russia

Maria Sergeyevna Egorova

Senior lecturer, Department of Economics of Institute of Social and Humanitarian Technologies, Tomsk Polytechnic University, Tomsk, Russia

Nataliya Valerievna Varlacheva

PhD, Department of Economics of Institute of Social and Humanitarian Technologies, Tomsk Polytechnic University, Lenin Avenue 30, Tomsk 634050, Russia

Email: varlacheva@gmail.com

\section{Doi:10.5901/mjss.2015.v6n2s4p35}

\section{Abstract}

In the article the industrialization is considered as a permanent process, so the hypothesis is offered about that it has stages and intervals of transition between stages. The aim of the study is definition of the intervals of transition of industrialization of such countries as Denmark, Norway, Canada, the USA, Japan, China and Russia in the following stages: early industrial and industrial, and conduction of the measurement of the modern state of studied countries. Determination of the intervals of transition is conducted on the basis of indicators of dynamics, such as rate of the export growth, rate of machine-building production export growth and rate of GDP. The conclusion was made about presence of early industrial, industrial and modern interval of the transition among studied countries, the signs of industrial transition interval signs were separated, and also the estimation of future trajectory of the development of countries was given.

Keywords: industrialization, transition interval, development of countries, industrial interval of the transition.

\section{Introduction}

Approaches to the study of questions of industrialization are differently interpreted in the Russian and foreign literature. In foreign sources the industrialization equates with the possibilities and structural changes which it gives, transforming the sources of the economic growth. The most famous foreign model of industrialization, called "the classical model of industrialization" was created by S. Kuznets and in 1960s added by H. Chenery et al. (1986) and S. Kuznets (1973). S. Kuznets proved that on the basis of GDP structure change, the changes of working labour number in different segments of economy and changes of the export structure it is possible to trace and estimation of different stages of the individual country economic development - agrarian, agro-industrial, industrial (Kuznets, 1973). H. Chenery determined that structural changes, caused by the industrialization, are also displayed in the change of demand elasticity according to the profit, when the growth reduction of the food product consumption takes place H. Chenery et al. $(1960 ; 1968 ; 1975$; 
1986).

In the Russian economic literature of prerevolutionary period we can separate three basic conceptions - formation, civilization and institutional directions, as a result of which confrontation the formation approach prevailed, that became the dominating one in the times of economic thought of the USSR (Zinoviev, 1996; Krasilnikov et al. 1994; Grigoriev \& Parshina, 2013). Here the industrialization is considered as the process of predominant development of manufacture of the production means and increase of their role in the growth of labour productivity in the economy on the whole. On the modern stage it is possible to mark the change of views about understanding of industrialization within the transition from formation approach to civilization one, expressed in the perception of industrialization of endless process of technical and technological changes (Pogrebinskaya, 2009; Grigoriev \& Parshina, 2013). As opposed to the foreign economists the Russian scientists could separate not only the stages of society development, but the stages of industrialization: from proto-industrial to postindustrial (Pogrebinskaya, 2009).

Synthesizing the views of foreign and Russian economists, we suppose that industrialization is permanent process that has stages and certain intervals between stages (intervals of transition).

We adhere to the positions of Russian scientists about permanence of industrialization; however, we suppose that changes in economic structure are not determined by the industrialization stage, but the intervals between stages, what we call the interval of transition.

\section{Results and Discussion}

The aim of the article is determination of the transition interval and its signs in the conditions of society industrial development.

For studying the transitivity of industrialization as economic phenomenon we'll rely on the methodological approaches of foreign economists, namely on the fact that changes in the economic structure must be compulsory reflected not only in the internal transformations, but first of all in the external, i.e. in the change of export structure (what was spoken about by S. Kuznets (1973), H. Chenery et al. $(1975,1986))$.

However, the export structure reflects only the result of change, considering the transformation process we cannot rely on the indicator, so we offer to introduce the range of new parameters, which show the dynamics of changes:

- Export growth rate

- Machine-building production export growth rate

- GDP growth rate

These indicators were chosen not randomly. The necessity of accomplishment of industrialization was caused by the economic delay from the other more developed countries, so the basic aim of industrialization becomes leading the country on the new level of economic development that display itself in higher economic growth rates, and higher level of life. It is provided owing to the reduction of production expenses, increase of the labour productivity based on the machine labour and acquisition of the comparative advantages in the foreign trade by the country that allows it to take the steady segment in the international trade. The process of search of the new positions in the international trade in the conditions of industrial society formation and its development compulsorily must be accompanied by the export transformation, that in the dynamics allow evaluating such parameters as the export growth rate and machine-building production export rate (as the basic components of industrialization) and GDP growth rate.

Export growth rate is calculated according to the formula:

$\operatorname{Tgr}(\operatorname{Exp})=[(\operatorname{Exp} 1-\operatorname{Exp} 0) / \operatorname{Exp} 0]^{\star} 100 \%$,

where Exp 0 - the values of export cost for the basic period (period before changes), Exp1 - the value of export cost for the current period (period after changes).

Machine-building production export growth rate is calculated according to the formula:

$\operatorname{Tgr}($ EXPman $)=[(\operatorname{Exp} 1-\operatorname{Exp} 0) / \operatorname{Exp} 0] * 100 \%$,

where Exp0 - the values of the machine-building production export cost for the basic period (period before changes), Exp1 - the values of the machine-building production export cost for the current period (period after changes).

GDP growth rate is calculated according to the formula:

$\operatorname{Tgr}(\mathrm{Y})=[(\mathrm{Y} 1-\mathrm{Y} 0) / \mathrm{Y} 0] * 100 \%$,

where $\mathrm{Y} 0$ - the values of GDP volume for the basic period (period before changes), $\mathrm{Y} 1$ - the value of GDP volume for the current period (period after changes).

We suppose that the interval transition of the country in the new stage of the industrial development will be designated by the spasmodic change of these parameters that displays itself in the growth rates more than $100 \%$.

Thus, the interval of transition in the early industrial stage can be determined in the case of excess of $100 \%$ of 
export growth rates and machine-building export growth. The value of GDP growth rates can sometimes not exceed $100 \%$. It is connected with the fact that formation of the industrial sector is only formed, the new segment in economy appears, the process of working labour movement into the industry begins. This promotes to the economic growth, which additional source is export of the industrial goods, however, in full extent it cannot reflect on the increase of the economy effectiveness, as the traditional segment of economy prevail - the agrarian sector.

The interval of transition into industrial stage must be compulsorily accompanied by the increase of $100 \%$ export growth rates, machine-building production export growth, and GDP growth rates. It is connected with radical changes of economic structure, where the basic chain is the industrial sector that is formed on the basis of machine-building complex. Consequently, being the economy basis, the industry creates completely new correlations, expressed in the change of production relations, in the new export structure and new position of the country on the international arena.

For confirmation of our hypothesis we conducted the analysis of these parameters in 6 countries - Norway, Denmark, Japan, the USA and China. The beginning of analysis - 1900 year, end - 2013 year. We divided the period of study for 10-year interval. It was possible to conduct the study on such countries as Norway, Canada, Denmark, the USA and Japan on all time intervals, and on China beginning since 1970 as a result of absence of the required information in the reliable international databases (Index Mundi, n.d.; Word Economics, 2013; Un Trade Statistics, 2013).

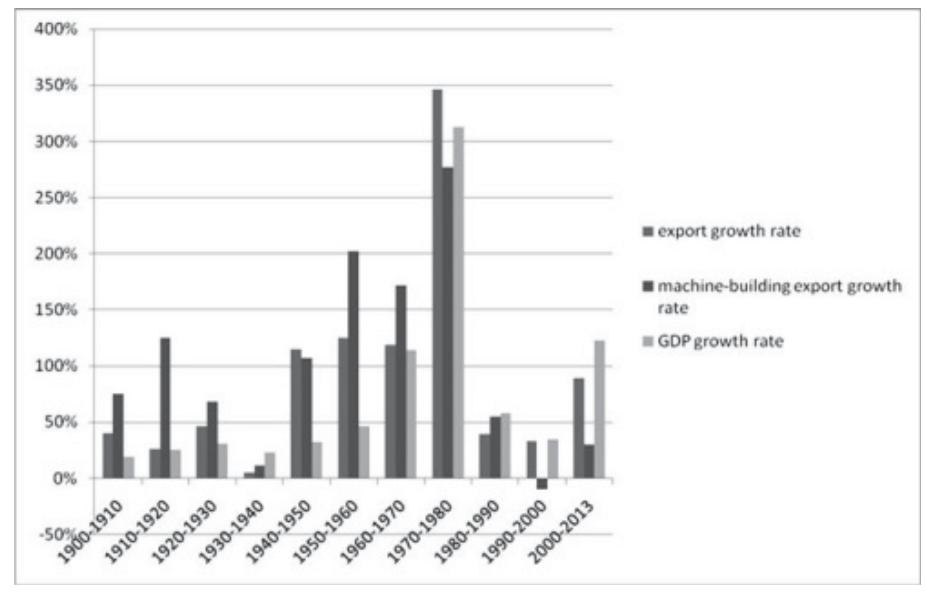

Figure 1: Indicators of the dynamics for Norway 1900-2013

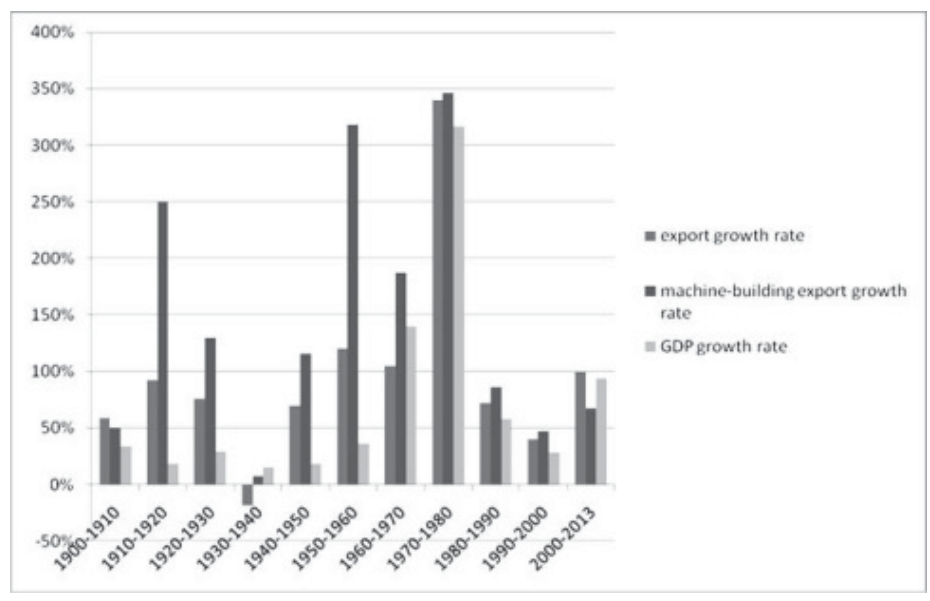

Figure 2: Indicators of the dynamics for Denmark 1900-2013 


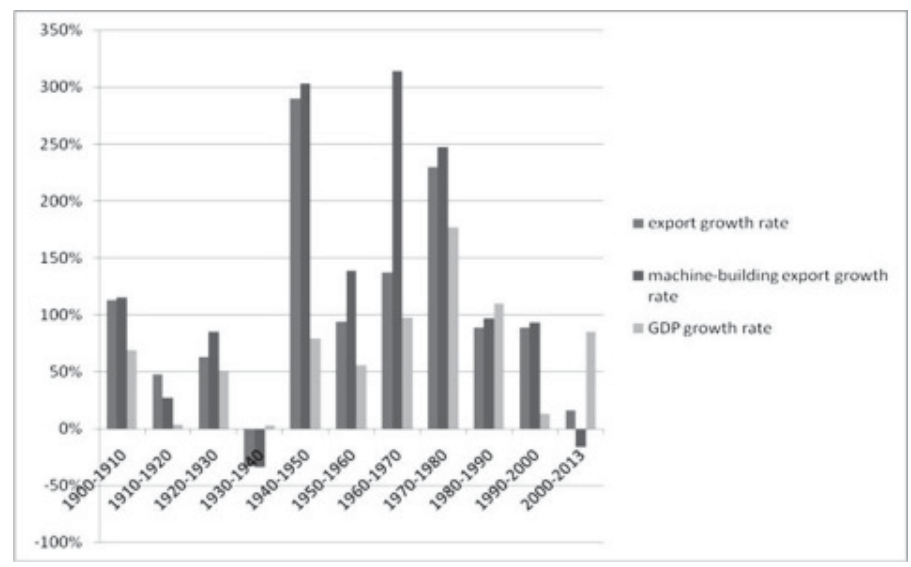

Figure 3: Indicators of the dynamics for Canada 1900-2013

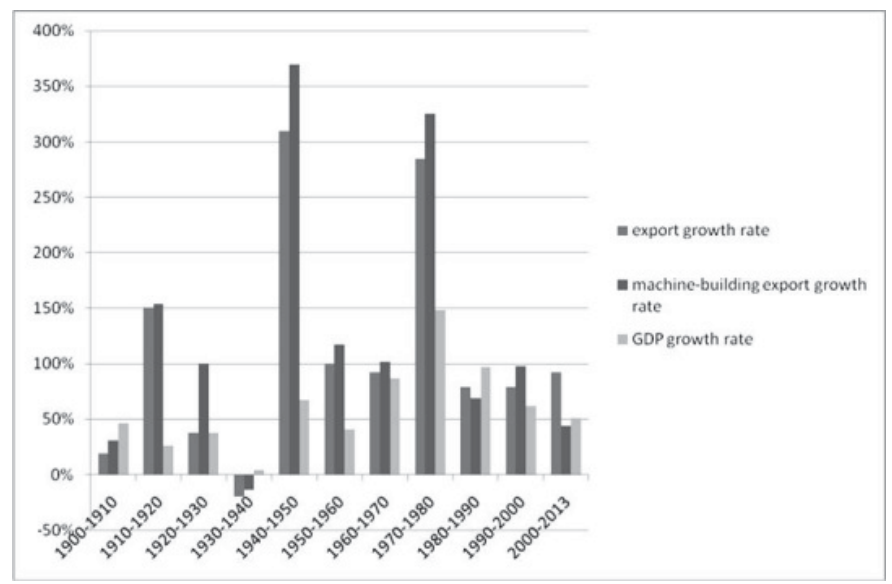

Figure 4: Indicators of the dynamics for the USA 1900-2013

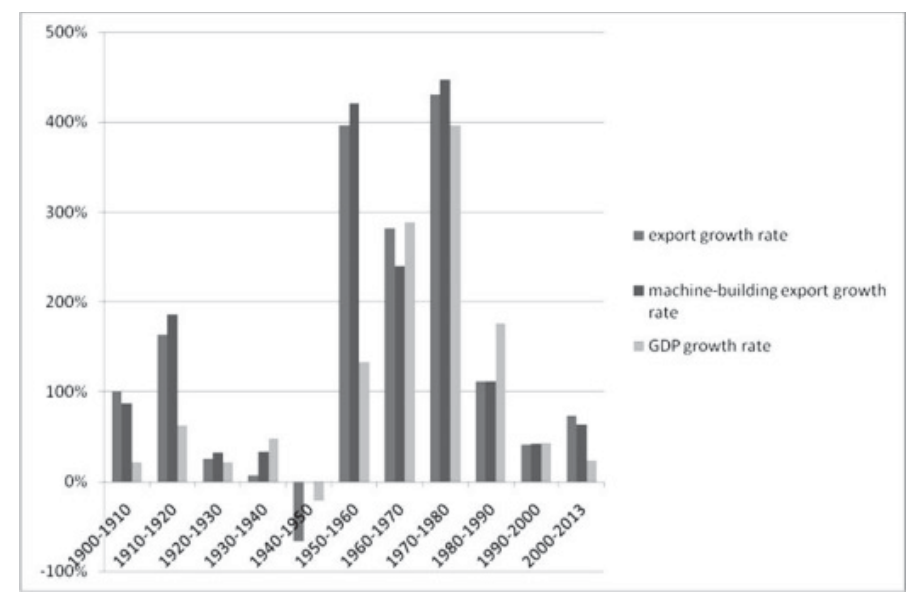

Figure 5: Indicators of the dynamics for Japan 1900-2013 


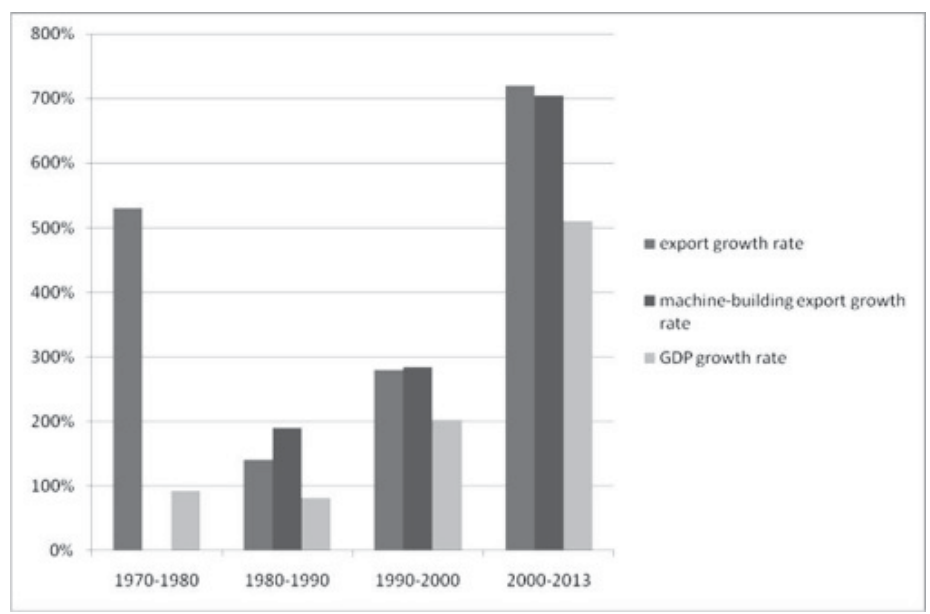

Figure 6: Indicators of the dynamics for China 1970-2013

As a result of study we came to the following conclusions.

The transition into early industrial stage in the considered countries finished to 1920 and took 10-year interval. It is brightly expressed in such countries as Denmark, Canada, Norway, Japan and the USA and in Norway - it is fuzzy. We understand it by non-conformity of such parameters as export growth rate and machine-building production export growth rate. The machine-building production export growth rate exceeds 100\%, and the export growth rate doesn't reach the value of the previous period. It tells about that the forming new industrial segment exists independently, in the gap from the basic external trade activity, some "dichotomy" forms. Small industrial sector doesn't add the export sources, but functions on its own.

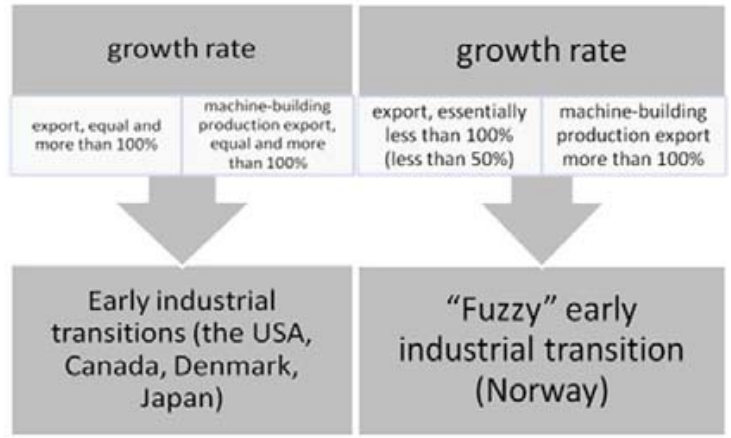

Figure 7: Types of early industrial transition

Transition into the industrial stage finished to 1980 for Denmark, Norway, Canada, the USA, having taken 10-20 years, to 1990 for Japan, having taken 40 years, transition into the industrial stage in China hasn't finished yet, having begun in 1990.

Having studied properly this interval of transition, we see the interesting peculiarity: each country, except for Japan, before to pass the interval of transition into industrial stage, the considerable period of time of accumulation of export potential was observed, that displayed itself in the exceeding 100\% export growth rates and machine-building production export growth rates: in Norway and Canada - since 1940 to 1960, in Denmark - since 1950-1960, in the USA - since 1940-1970, in China -1970-1990. To this time the countries essentially grew the part of machine-building products in the structure of export (averagely in 2-3.5 times) in comparison since 1910-1920s. The value of machine-building share in export for each country varied averagely from $40-80 \%$ (for example, in Denmark - 40\%, Norway - 45\%, China - 80\%). Intensification of the export, based upon machine-building complex products that displayed itself in the exceeding of $100 \%$ of GDP growth rates. The time limits of the economic burst coincide with the time limits of the industrial transition 
interval. In the course of historical development of one, two, three, five fold increase of the speed of GDP growth in different countries was observed only in the conditions of transition into the industrial stage.

Thus, in Norway GDP growth rates since 1960 to 1970 reached 114\%, since 1970 to 1980 - 313\%, in Canada $100 \%$ and $177 \%$ accordingly, in Denmark - 140\% and 317\%, in the USA since 1970 to $1980-148 \%$, in China - since 1990 to $2000-203 \%$, since 2000 until now $-511 \%$.

Japan is the only country, where the period of accumulation of export potential was absent, and the time of industrial transition began in a moment and characterized as economic burst during 40 years since 1950 to 1990. Thus, since 1950 to 1960 the GDP growth rates made $133 \%$, since 1960 to $1970-289 \%$, since 1970 to 1980 - 396\%, since 1980 to $1990-176 \%$.

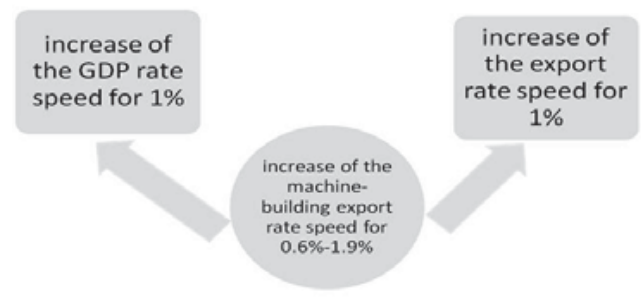

Figure 8: Effect of the machine-building growth on the economic growth

The time of economic burst was characterized not only with the considerable increase of the economic growth and export rates, but also evident interrelation between increase of the machine-building export speed and GDP growth speed increase and total export.

Thus, the machine-building production export growth in China for $1 \%$, Norway and Denmark on $0.6 \%$, Japan and Canada for $1.4 \%$ and in the USA for $1.9 \%$ promoted to the GDP growth for $1 \%$. The machine-building production export growth in Chine for $1 \%$, Norway and Denmark for $0.6 \%$, Japan for $1.2 \%$, Canada for $1.5 \%$ and in the USA for $1 \%$ promoted the total export growth for $1 \%$.

Thus, we can make the following conclusions.

The sign of transition into early industrial stage of industrialization is exceeding of $100 \%$ of export growth rates and machine-building production export rates, at that transition can be brightly expressed or "fuzzed" (as in Norway).

Table 1: Signs of industrial transitions, which were preceded by the period of accumulation of machine-building export potential

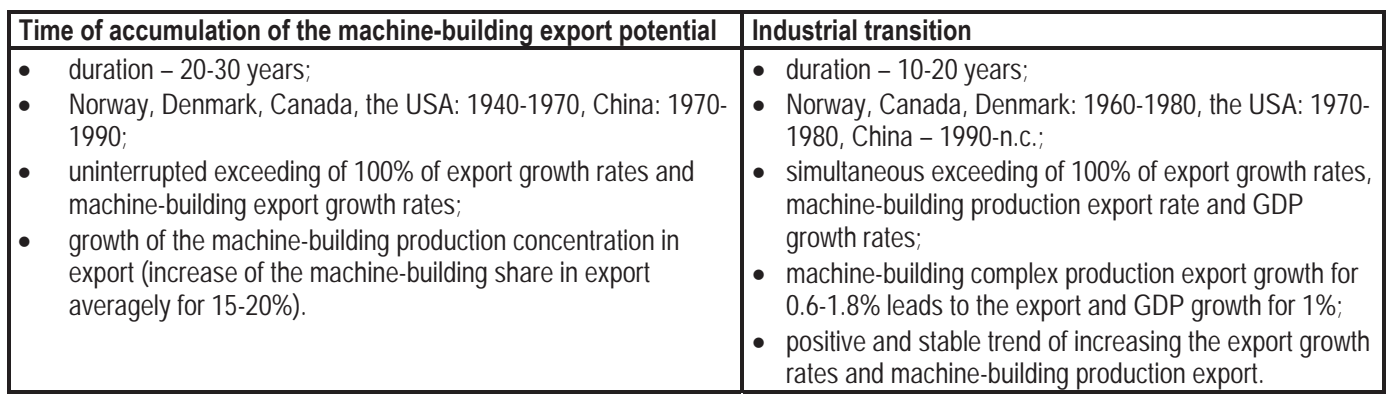

The sign of transition into industrial stage is simultaneous exceeding of $100 \%$ of the export growth rates, machinebuilding production export and GDP. The transition is accompanied with economic burst, which precedes by the time of accumulation of export industrial margin (from 20 to 30 years) that is expressed in uninterrupted exceeding of $100 \%$ export growth rates and machine-building production export growth rates, as well as in accumulation of the machinebuilding production concentration in the export of the country. Export resource of the country, which center is the machine-building production, creates conditions for acceleration of the economic development and transition into industrial stage. This interrelation can be measured through correlation of the export growth speed of the machine- 
building complex production and GDP. Thus, the increase of the machine-building export growth speed increase from $0.6 \%$ to $1.8 \%$ in different countries promoted to the export growth and GDP for $1 \%$. This industrial transition was demonstrated to us by Norway, Canada, Denmark, the USA and China.

The industrial transition of Japan was not preceded by the period of export potential accumulation that prolonged the interval of transition since 10-20 years to 40 years and was reflected on the unsteady trend of increasing the export growth rates and machine-building production export growth rates (it has fluctuation character). For example, for 19501960 the machine-building export growth rate made 421\%, and the next decade $-240 \%$. However, it didn't reflect essentially on the economic development of Japan, the country could make the economic burst, at that with the same proportions of effect of the machine-building export growth rates on the economic growth. Thus, $1.1 \%$ of machine-building complex production export growth of Japan led to the export growth and GDP for 1\%.

Being guided by our logic further we'll determine the modern state of the studied countries. It is known that the opinion exist about post-industrial economies, where not simple machine-building complex (MBC) becomes the leading one in the economy, but MBC based on high technologies. Consequently, we'll estimate the presence of the transition interval, being guided not only on the values of machine-building export change, but on the dynamics of hightechnological production export dynamics, which core is machine-building again. We'll compare these indicators with the export growth rate and GDP growth rate.

As a result of calculation we came to the following data.

Table 2: Indicators of country dynamics on the modern stage of development, \% (Index Mundi, n.d.)

\begin{tabular}{|l|c|c|c|c|c|c|}
\hline & \multicolumn{2}{|c|}{$\mathbf{1 9 9 0 - 2 0 0 0}$} & & \multicolumn{2}{|c|}{ 2000-n.c. } & \\
\hline & $\begin{array}{c}\text { Export } \\
\text { growth rates }\end{array}$ & $\begin{array}{c}\text { High-technological } \\
\text { export growth rates }\end{array}$ & $\begin{array}{c}\text { GDP growth } \\
\text { rates }\end{array}$ & $\begin{array}{c}\text { Export } \\
\text { growth rates }\end{array}$ & $\begin{array}{c}\text { High-technological } \\
\text { export growth rates }\end{array}$ & $\begin{array}{c}\text { GDP growth } \\
\text { rates }\end{array}$ \\
\hline Denmark & 40 & 193 & 28 & 99 & 79 & 94 \\
\hline Norway & 33 & 91 & 32 & 89 & 144 & 123 \\
\hline Canada & 89 & 185 & 13 & 16 & 5 & 85 \\
\hline USA & 79 & 136 & 62 & 92 & 22 & 51 \\
\hline Japan & 41 & 72 & 43 & 74 & 21 & 24 \\
\hline China & 280 & 587 & 203 & 720 & 995 & 511 \\
\hline
\end{tabular}

The received data allow us speaking about that the evident signs of post-industrial transition are not observed: in Canada and the USA the GDP growth rate is insufficient in all countries, except for China, the correlation of the high-technological export growth rates and total export is unstable. Japan still doesn't show evident signs of transition into new economic quality, however, taking into account the historical legacy of this country and remembering that it is able to accelerate in a moment, having mobilized the internal resources, it is early to make conclusion about it. On the whole, we can't speak about transition in post-industrial state, as the simultaneous correspondence of three indicators is observed: export growth rates, high-technological export growth rates and GDP growth rates.

On this background the meanings of China are separated. We must remember that the industrial transition was marked in the country in 1990-2000s, by no means regularly flowing from the base, grounded on the classical machinebuilding, on the principle of high-technological machine-building. However, we can't say with high degree of reliability that today China passes post-industrial transition in connection with insufficiency of time lag.

Today together with it there are displays of transition into the stage preceded by post-industrial one. If compare with historical development, then the analogue of modern transition we find in 1900-1920s, when the countries made transition in the early industrial stage, which forestalled the industrial one. Thus, we suppose that in 1990-2000 the USA and Canada made transition into late industrial state, presently these countries, as Denmark, Norway and China are in the interval of transition to late industrial stage, where the forming high-technological complex begins to change the structure of economy, transforms the structure of export and sources of economic growth. 


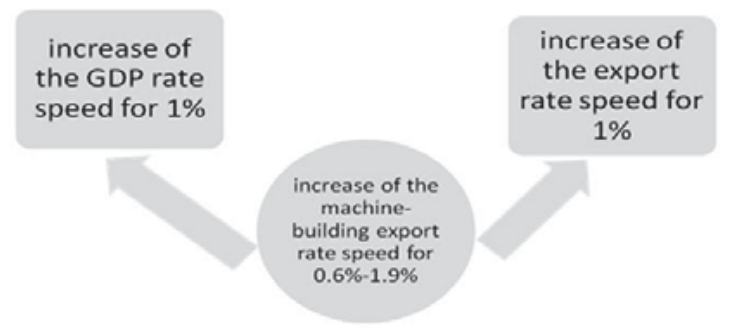

Figure 9: Peculiarities of late industrial transition

It is possible to suppose that if the countries grow the speed of high-technological production concentration in export (in 2-3 times), then in the nearest future, the accumulation of high-technological export potential will happen that in 20-30 years allow countries making new economic burst on the completely new technological base and mean the transition into postindustrial stage, where the export of high technologies will be the engine of economic development.

Having checked the algorithm of determination of transition interval on the time segment 1900-2013 and by the way of comparison of several heterogeneous countries, we were convinced in its reliability. Further, we'll test this method in relation to the economy of Russia on the basis of Rosstat data and statistical digests of estimation of national economic development of the USSR (Historical Materials, 1990).

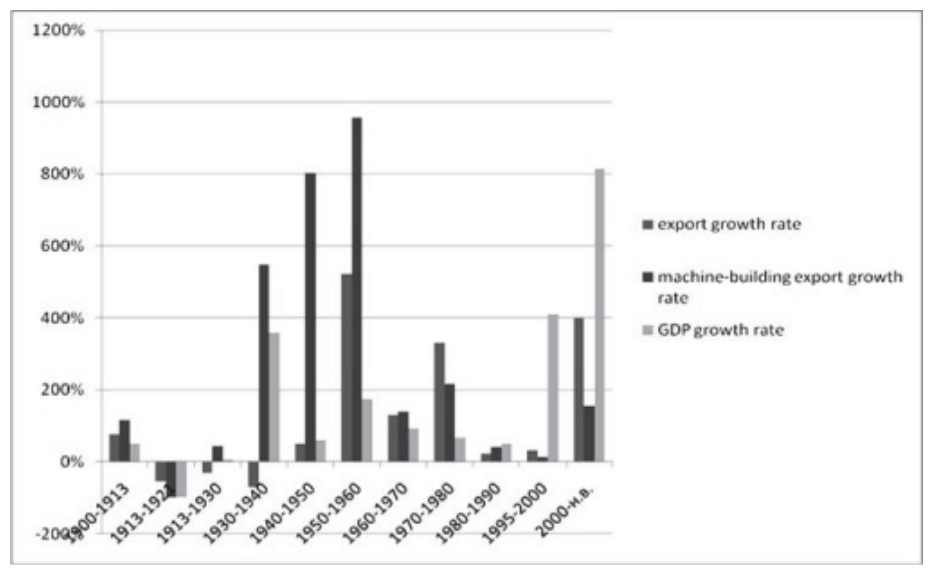

Figure 10: Indicators of the dynamics of Russia 1900-2013

The analysis of data shows us that transition in early industrial stage in Russia finished to 1913, however similar as in Norway, is characterized by "fuzziness", namely by that formation of industrial base in the country didn't form the dependence of the export from its production. The following years of the First World War and Civil Revolution and their consequences (including Holocaust 1921-1922) caused catastrophic complication for the Russian economy. Thus, the decline 1913-1921 was so strong that if orient on the meaning of export and national profit in these years, then it can appear that 1920-1930 years are the golden age of economy. However, it is not so, that's which within the frameworks of the analysis conducted by us, it is more appropriate to consider the period since 1913 to 1930 that shows the degree of damage for the economy of the country from military actions - it is the absence of economic growth rate and negative rates of internal trade activity.

Further, we can mark the shapes of the period of machine-building export potential accumulation, however, they are smoothed and one-sided as a result of absence of the considerable the USSR export growth rates: for the period 1930-1940 they make -70\%, 1940-1950 +52\%. It is conditioned by the economic backwardness 1930s (after 20 years of the most difficult crisis), closeness of economy and destructive consequences of the Second World War, when the basic efforts were directed on the restoration of the internal economy. 
Table 3: Interval of the USSR industrial transition and its peculiarities

\begin{tabular}{|c|c|}
\hline Time of accumulation of the machine-building export potential & Industrial transition \\
\hline $\begin{array}{l}\text { - duration - } 20 \text { years; } \\
\text { - USSR: } 1930-1950 ; \\
\text { - } \quad \text { grinterrupted exceeding of } 100 \% \text { of machine-building export } \\
\text { growth of the machine-building production concentration in } \\
\text { export (increase of the machine-building share in export from } \\
\text { 2\% to 20\%). }\end{array}$ & $\begin{array}{l}\text { - duration - } 20 \text { years; } \\
\text { - } \quad \text { period - 1950-1970; } \\
\text { - } \text { simultaneous exceeding of 100\% of export growth rates, } \\
\text { machine-building production export rate and GDP growth } \\
\text { rates; } \\
\text { - machine-building complex production export growth for } \\
\text { 0.1-0.4\% leads to the export and GDP growth for 1\%; } \\
\text { - positive, but unstable trend of increasing the export growth } \\
\text { rates and machine-building production export. }\end{array}$ \\
\hline
\end{tabular}

We can state the fact of industrial transition of the USSR 1950-1970 on the basis of correlation of three parameters export growth rates, machine-building export and GDP, and that they exceeded 100\%. Basically, the industrial transition was characterized by the same parameters as the industrial transition of other countries did. However, the proportions of the machine-building export effect on the economic growth and internal trade activity was lower. The production export growth of machine-building complex for $0.4 \%$ led to the national profit growth for $1 \%$, and the production export growth of machine-building complex for $0.1 \%$ promoted to the export growth for $1 \%$. This tells about that the economy of the USSR was more sensible to the industrial sector expansion, than the economy of other considered countries. It was conditioned by the fact that the USSR more than the other considered countries suffered from the consequences of war, having the huge deficiency of labour and material resources, however, the industrial base, founded in 1930, was the source of mobilization of internal reserves and its expansion and became the determinative one in the growth of labour productivity and the national profit.

The positive, but unstable trend of accumulation of export growth rates and MBC production export was observed as in Japan. Generally, the transition into the industrial state is coincided with the process of transition of other countries and on time intervals, and on the parameters of dynamics.

The analysis of the modern state of Russia's economy is of great interest. For the last decade the GDP growth rate makes the top meaning for the country $-814 \%$, export growth rates $-411 \%$. It can be explained partially by the essential failure of Russia's economy in 1990s, connected with the transition from planned to market economy, when in 2000 according to the value of GDP and export the economy didn't reach values of 1990 year. We remember that in other considered countries the transition into late industrial state is characterized by the "fuzziness", but can we assert that Russia made late industrial transition? No, we can't.

In order that we could be persuaded in the transition, it is necessary to compare two parameters: export growth rates and high-technological export growth rates. If the export growth rates are high, then the high-technological export growth rates are extremely low - for the last decade made 39\%. Consequently, the high-technological complex is not the source of modern development.

Let's determine the value of production export growth rates of machine-building complex, it makes $114 \%$ for the period of 2000-2013. The exceeding of three parameters of the process dynamics exceeds (and sometimes goes off scale) $100 \%$, and for the first sight, it can mean the repeated transition into the industrial stage.

Firstly, the analysis of other countries shows that there can be possibility of doubling the transition, but it must not appear. Secondly, independently whether the transition is preceded or not by the period of accumulation of the machinebuilding export potential, the concentration of machine-building must growth to the moment of transition, i.e. the increase of the machine-building share in export must happen, or at least, don't reduce. For the period of 1996-2013 the reduction of machine-building share took place in the structure of production export of Russia from $26 \%$ to $13 \%$. Thirdly, in the conditions of modern transition in the Russia's economy the proportions of the dependence of export growth rates of machine-building, total export growth rates and GDP growth rates were violated.

For the growth of the Russian economy for $1 \%$, the increase for $5.6 \%$ of the machine-building export value and for $6.3 \%$ of total export is required. For the interval of transition into industrial state, the following things are not peculiar: sensibility to the industrial sector in each country is individual and determined by the previous historical and current level of the development, but doesn't exceed $1.8 \%$. In the economy of Russia - nearly $6 \%$, this means that on the modern stage of the development, it is necessary to increase the export capacity more that in 3 times in comparison with 19501970s in order that to attain the corresponding economic growth rates, at that it is not the export basis of MBC products, and especially high-technological complex. 
The obtained data allow speaking about that Russia is in the state of transition, but it remains unclear of its type, because it couldn't be related either to the industrial one, or especially to the late industrial one.

We come to understanding that the algorithm of determination of the signs, and interval of industrialization transition can't explain the differences in the displays of industrialization conducted in each country and their specificity: "fuzziness" of early industrial transition of Norway and Russia, late industrial transition of Norway, Canada, Denmark and the USA and vagueness of the nature of Russia's transition. However, it goes beyond the frameworks of this research and has been partially reflected in the literature already (Nekhoroshev \& Korneva, 2011; Pluzhnik, 2013; Pumiantseva, 2012; Riazanov, 1998).

\section{Conclusion}

Thus, the obtained data allow making the following conclusions. Comparing the uneven changes of export growth rates and machine-building export growth rates, we determined the interval of early industrial transition of such countries as Japan, Denmark, Norway, Canada, the USA and Russian Empire, - 1900-1920s.

Comparing the uneven changes of export growth rates and GDP growth rates and machine-building production export growth rates, we determined the interval of industrial transition of studied counties, except for China that is still in the state of transition, $-1960-1990$ s.

Comparing the uneven changes of export growth rates and high-technological production export growth rates, we determined that studied countries except for Russia since 1990s are in the conditions of late industrial transition.

In connection with the fact that the industrial transition considerably changed the economic structure of the society, we described its signs, acknowledging machine-building concentration growth to be the most essential in the structure of export on the threshold of transition or during transition (for example, Japan), as well as the presence of interrelation between machine-building production export acceleration on the economic growth of the countries.

It gave possibility to suppose that the process of transition can be managed. Thus, researching the future trajectory of the development of countries, we can assert that high-technological production concentration accumulation in the structure of export in 2-3 times will promote to the transformation of the export source and economic growth, that leads to the competitive ability increase on the world market and acceleration of the economic development of the countries.

\section{References}

Amosov, A.I. (2009). Consequences of superacceleration of economical and social evolution in the last centuries: Regularities of social and economic development. Moscow: Publishing House LKI.

Babintseva, N.S. (1998). Industrialization: historical experience and present. Saint-Petersburg: Publishing-House of Saint-Petersburg University.

Chenery, H., \& Syrquin, M. (1975). Patterns of Development, 1950-70. New York: Oxford UniversityPress.

Chenery, H., \& Taylor, L. (1968). Development Patterns among Countries and over Time. Review of Economics and Statistics, 50, $487-$ 521.

Chenery, H., Robinson, S., \& Syrquin, M. (1986). Industrialization and Growth. A Comparative Study. New York: Oxford University Press.

Chenery, H. (1960). Patterns of Industrial Growth. American Economic Review, 50(4), 624-654.

Grigoriev, L.M., \& Parshina, E.N. (2013). Economic dynamics of the countries of the world in 1992-2010: irregularity of the growth' Bulletin of S.-Petersburg University, 4, 70-87.

Historical Materials (1990). The national economy of the USSR [Online]. Available: http://istmat.info/node/21341 (June/2014).

Index Mundi (n.d.). [Online]. Available: http://www.indexmundi.com/ (January 2015).

Krasilnikov, V., Belousov, A.P., Gutnik, V., Clepach, A.N., \& Kuznetsov, V.I. (1994). Modernization: Foreign experience and Russia. Moscow: Informat.

Kuznets, S. (1973). Modern Economic Growth: Findings and Reflections. American Economic Review, 63, 247-258.

Lenin, V.I. (1969). Issues of the socialism and communism development. Moscow: Politizdat.

Nekhoroshev, Yu.S., \& Korneva, O.Yu. (2011). Character of the economic structure in the post-industrial society. Economic Analysis Theory and Practice, 1, 2-6.

Pluzhnik, M.V. (2013). Determinants of industrialization: retrospective analysis. Economy and Entrepreneurship, 10, 75-80.

Pluzhnik, M.V. (2013). Renaissance of the material production in Russia as the condition of provision of economic safety. Business. Law. Education. Bulletin of Volgograd Institute of Business, 2, 161-166.

Pogrebinskaya, V.A. (2009. Institutional peculiarities of the industrialization beginning of Russia (the last third of XIX - beginning of XX cent.). Doctoral dissertation. Moscow: Lomonosov Moscow State University.

Pumiantseva, S.Yu. (2012). Peculiarities of modern phase of the world economic conjuncture. Bulletin of S.-Petersburg University, 5, iss. 3, 3-20. 
Riazanov, V.T. (1998). Economic development of Russia. Reforms and Russian economy in 19-20 centuries. Saint-Petersburg: Nauka. Rostow, W.W. (1960). The Stages of Economic Growth: A Non Communist Manifesto. Cambridge: Cambridge University Press.

Un Trade Statistics (2013). Monthly Bulletin of Statistics Analytical Trade Tables. [Online]. Available: http://unstats.un.org/unsd/trade/ data/tables.asp (January 2015).

Word Economics (2013). Maddison Historical GDP Data. [Online]. Available: http://www.worldeconomics.com/Data/MadisonHistorical GDP/Madison\%20Historical\%20GDP\%20Data.efp (January 2015).

Zinoviev, V.P. (1996) Stages of industrial society formation in Russia. Civilized and Formation Approaches to Study the Native History: Theory and Methodology (concrete-historical problems), 3, 25-30. 
